DOI 10.4467/2543733XSSB.17.003.9978

\title{
GENEZA I POCZĄTKI KONFLIKTÓW ETNICZNYCH NA CYPRZE DO ROKU 1912
}

\section{Origins of the ethnic conflicts in Cyprus}

\author{
Summary
}

Numerous studies of the so-called "Cyprus problem" are devoted mainly to particular phases of the conflict, especially the period from 1958 to 1960, the activities of the EOKA, the period 1960-1964, the problems of the newly created republic and the 1974 division of Cyprus. Only rarely do we find references to the earlier history of Cyprus and there are still only few objective academic papers showing the genesis of the conflict.

The article presents the origins of ethnic conflicts of Cyprus, discussing the theories of the origin of the island's first inhabitants, and the arrival of numerous Muslims on the island after the Turkish conquest in the 16th century. During the next three centuries, regardless of the subsequent developments, peaceful coexistence and fruitful cooperation of both communities - Christians and Muslims - are an authentic historical event and are not subject to any doubts. The situation began to change after the begining of the so-called "Cultural war" caused by, among others things, by spreading the idea of Great Greece. The takeover of Cyprus by the British in 1878 only strengthened the hopes of the Greek Cypriots of joining the island to Mother Greece, which resulted in the rise of nationalist feelings, both among Greek and Turkish Cypriots, and eventially led to the outbreak of the first ethnic conflicts in 1912.

Keywords: Cyprus, Greek Cypriots, Turkish Cypriots, conflict, the Cyprus dispute, nationalism

Słowa kluczowe: Cypr, greccy Cypryjczycy, tureccy Cypryjczycy, konflikt, problem cypryjski, nacjonalizm

Na wstępie należy zaznaczyć, że na temat tzw. „problemu cypryjskiego” powstała w ciągu ostatnich 50 lat bardzo bogata literatura, niemniej w olbrzymiej większości zajmuje się ona poszczególnymi fazami konfliktu między greckimi i tureckimi Cypryjczyka- 
mi, szczególnie okresem od 1958 do1960 roku i działalnością EOKA, okresem 1960-1964 i problemami nowo powstałej republiki oraz roku 1974 i podziałem Cypru ${ }^{1}$. Znaczna jej część stanowią narracje i pamflety, które już w swoim zamierzeniu mają cel propagandowy: zazwyczaj historycy związani z Grecją obarczają winą za wszelkie dramatyczne wydarzenia tureckich Cypryjczyków i ich protektorów ${ }^{2}$, Turcję; historycy związani z Turcją - grec-

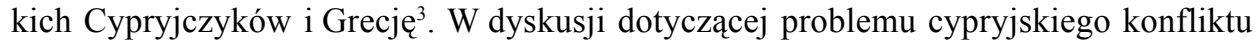
z rzadka jedynie znajdujemy odwołania do wcześniejszej historii Cypru i nadal brak jest opartych na materiałach źródłowych, obiektywnych akademickich opracowań pokazujących genezę konfliktu ${ }^{4}$.

Pierwsze poważne incydenty z powodów nacjonalistycznych miały miejsce na Cyprze w maju 1912 r. Wcześniej zamieszkujące Cypr społeczności greckich Cypryjczyków, którzy byli w olbrzymiej większości prawosławnymi chrześcijanami, oraz tureckich Cypryjczyków, którzy byli muzułmanami, żyły na ogół zgodnie, szczególnie wieśniacy i ubodzy mieszkańcy miast. Chrześcijanie i muzułmanie mieszkali razem na Cyprze przez ponad 300 lat i, niezależnie od późniejszego rozwoju wypadków, ich pokojowe współistnienie i owocna współpraca są autentycznym wydarzeniem historycznym i nie podlegają żadnym wątpliwościom ${ }^{5}$. Przynajmniej niektóre masowe protesty i bunty były organizowane wspólnie, bo tak chrześcijańscy jak i muzułmańscy raja mieli powody, by narzekać na surowy

\footnotetext{
${ }^{1}$ Polska historiografia tego okresu to przede wszystkim prace politologów, które jednak nie zajmują się genezą konfliktu, np. studium Cypr - anatomia konfliktu (Warszawa 1975) autorstwa Beaty Niteckiej-Jagiełło, zredagowany przez Iwonę Lewandowską tom Cypr - podzielona wyspa, Warszawa 1988, a przede wszystkim obszerne omówienie Artura Adamczyka, Cypr. Dzieje polityczne, Warszawa 2002, obejmujące okres do 2002 r., i równie szczegółowa monografia Przemysława Osiewicza, Pokojowa regulacja kwestii cypryjskiej: aspekty prawne i polityczne (Torun 2008), doprowadzająca prezentację do roku 2007 oraz tegoż, Konflikt cypryjski, Warszawa 2013.

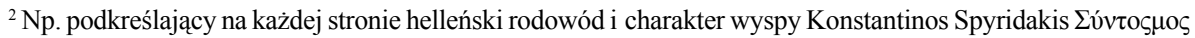

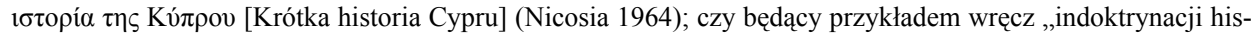
torycznej” wykład, od ponad trzydziestu lat używany jako podręcznik do historii Cypru w szkołach średnich: C. P. Georgiades, History of Cyprus (Nicosia, wiele wydań).

${ }^{3}$ Np. Oktay Öksüzoğlu, Persecution of Islam in Cyprus. A Document of Real Greek Intentions towards Muslim Turlish Cypriots 1982, H. F. Alasya, Klbrls Tarihi ve Klbrıs ta Türk Eserleri [Cypryjska historia i tureckie zabytki na Cyprze], 2. wyd. (Ankara 1964), czy spojrzenie współczesnych islamskich historyków: A. Etman, History of Cyprus: The Island of Beauty and Pain from Antiquity to the Present Day, thum. $\mathrm{z}$ arabskiego Ahlam Fathy Hassan, Cairo 2002. Najnowsze podsumowania dyskusji na temat różnego spojrzenia na wydarzenia na Cyprze daje Paul Griffiths, Memories of Violence in Cyprus: Conflicting Perspectives and Dynamics of Reconciliation, niepublikowana praca doktorska, University of Exeter, 2011.

${ }^{4}$ Por. M. Aymes, A Provincial History of the Ottoman Empire. Cyprus and the Eastern Mediterranean in the Nineteenth Century, translated Adrian Morfee, London 2014, s. 23-24; A. F. Reiterer, Cyprus. Case Study about a Failure of Ethno-national Understanding, Peter Lang, Frankfurt am Main 2003, s. 30-31. Zob. też ciekawy artykuł podsumowujący obecny stan badań dotyczący stosunków między greckimi i tureckimi Cypryjczykami, Y. Ioannou, A Bibliographical Guide to Ottoman Cyprus, [w:] Ottoman Cyprus. A Collection of Studies on History and Culture, ed. M. N. Michael, M. Kappler, E. Gavriel, Wiesbaden 2009, s. 311-356.

${ }^{5}$ Por. ważne choćby z racji zebranych materiałów źródłowych: C. P. Kyrris, Symbiotic Elements in the History of the Two Communities in Cyprus, [w:] International Symposium on Political Geography. Proceedings, Nicosia 1976, s. 127-166; C. P. Kyrris, Peaceful Co-existence in Cyprus under British Rule (1878-1959) and after Independence: An Outline, Nicosia 1977. C. P. Kyrris był jednym z głównych architektów politycznie motywowanej rewizjonistycznej historii, pokazującej pokojowe współistnienie między obiema społecznościami na Cyprze przed rokiem 1974, której celem było zminimalizowanie odpowiedzialności greckich Cypryjczyków za akty przemocy w latach 50., 60. i 70. XX wieku. Por. Divided Cyprus: Modernity, History, and an Island in Conflict, ed. Y. Papadakis, N. Peristianis, G. Welz, Bloomington, University of Indiana, 2006.
} 
system podatkowy i nieudolną administrację. W sferze ekonomicznej istniała jedność i wzajemna zależność. Nigdy nie było na Cyprze dwóch oddzielnych gospodarek - jednej chrześcijańskiej, drugiej muzułmańskiej, chociaż w niektórych branżach, takich jak budownictwo i stolarstwo, przeważali chrześcijanie. Z kolei muzułmanie wyspecjalizowali się w położnictwie, medycynie ludowej i tkactwie ${ }^{6}$.

Przedstawienie historii Cypru pod panowaniem tureckim różni się w zależności od przynależności etnicznej/religijnej historyka. Dla greckich Cypryjczyków historia wyspy w okresie turkokracji koncentruje się na działalności wybranych postaci, jak choćby arcybiskup Kyprianos czy dragoman Hadjigeorgakis Kornesios ${ }^{7}, \mathrm{i}$ dramatycznych wydarzeniach, takich jak egzekucja prawosławnej elity w roku 1821, i jest przedstawiana jako okres zniewolenia i tyranii ${ }^{8}$. Dla tych historyków Kościół prawosławny był główną nadzieją w kulturowych i edukacyjnych dążeniach należących do niego Cypryjczyków, a jego niesławna działalność polityczna i nadużycia ekonomiczne były przemilczane ${ }^{9}$. Z drugiej strony tureccy Cypryjczycy przedstawiają turkokrację jako okres tolerancji i wolności religijnej ${ }^{10}$.

Od lat dwudziestych XIX wieku wśród elity greckich Cypryjczyków zaczęła się dyskusja na temat przyszłości Cypru i związanych z tym problemów odnośnie do przeszłości wyspy i wpływów hellenistycznych (często dla uproszczenia nazywanych greckimi) oraz semickich (często dla uproszczenia zwanych tureckimi). Ta wymiana myśli, nie zawsze zresztą czysto akademicka, toczy się między historykami, archeologami i antropologami kultury do dzisiaj i przybiera często postać tzw. „,wojny kulturowej”11.

Jednym z głównych pytań jest kwestia pochodzenia pierwszych mieszkańców wyspy. Przybyli oni, według jednej teorii, z Bałkanów (Macedonia), a co za tym idzie, byli spokrewnieni z przodkami dzisiejszych Greków, albo, zgodnie z drugą - bezpośrednio z Anatolii, kolebki dzisiejszych Turków. Dopiero ostatnio, po znaleziskach w Klimonas (z 2011 r.) ustalono bezsprzecznie, że pierwsi mieszkańcy Cypru przybyli z kontynentu azjatyckiego, najprawdopodobniej z zachodniej Syrii ${ }^{12}$. Po okresie zamieszkiwania wyspy przez tzw.

${ }^{6}$ F. Beckingham, The Turks of Cyprus, The Journal of the Royal Anthropological Institute of Great Britain and Ireland, No 2, July-December 1957, s. 165-174; A.E. Özkul, Tradesmen (Esnaf) and their Products in 18 Century Ottoman Cyprus, [w:] Ottoman Cyprus, s. 197-208.

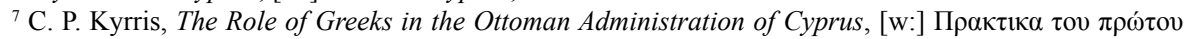

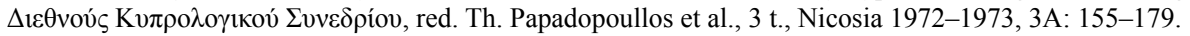

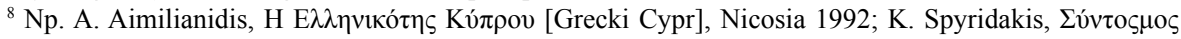

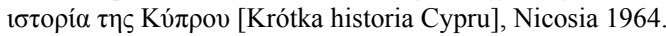

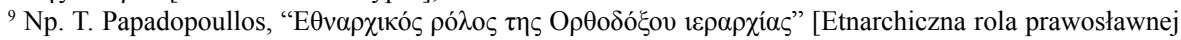

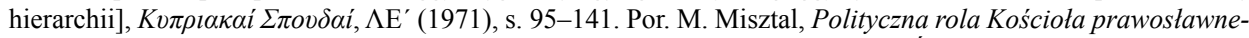
go na Cyprze w okresie turkokracji i na poczatku panowania brytyjskiego, Studia Środkowoeuropejskie i Bałkanistyczne, t. XXIV, 2016, s. 15-34.

${ }^{10}$ H. F. Alasya, Kıbrıs Tarihi ve Kıbrıs 'ta Türk Eserleri, Ankara 1964; K. Çiçek, Zimmis (Non-Muslims) of Cyprus in the Sharia Court: 1110/39 A.H./1698-1726 A.D., University of Birmingham, 1992; A. C. Gazioğlu, The Turks in Cyprus, Nicosia-London 1990.

${ }^{11}$ Zob. M. Misztal, Problem cypryjski a 'wojna kulturowa', [w:] Polska, Europa Środkowa, Europa Zjednoczona: księga jubileuszowa dedykowana profesorowi Józefowi Łaptosowi, red. Andrzej Kozera et al., Kraków 2014, s. 255-268; Y. Hamilakis, 'Learn History!' Antiquity, National Narrative and History in Greek Educational Textbooks, [w:] The Usable Past, Greek Metahistories, ed. K. Brown, Y. Hamilakis, Oxford 2003.

${ }^{12}$ N. K. Harper, Short Skulls, Long Skulls, and Thalassemia: J. Lawrence Angel and the Development of Cypriot Anthropology, „Near Eastern Archeology”, 71, nr 102, March-June 2008, s. 111-119; D. Vigne et al., First Wave of Cultivatons Spread to Cyprus at least 10600 Years Ago, „Proceedings of the National Academy of Sciences of the United States of America”, 109, nr 22, 22 May 2012, s. 8445-8449. 
Eteocypryjczyków ${ }^{13}$, na wyspie zaczęli się osiedlać uchodźcy mykeńscy. Napływ Achajów był niezwykle ważny dla przyszłości Cypru, bo doprowadził do zmiany zarówno cywilizacji wyspy, jak i etnicznego składu ludności, zaś tradycja homerycka miała prawdopodobnie duży wpływ na zwyczaje cypryjskich Mykeńczyków ${ }^{14}$. Greccy Cypryjczycy podkreślają, że achajska kolonizacja Cypru miała miejsce już około roku 1500 p.n.e., czyli że Hellenowie dotarli na Cypr dużo wcześniej niż Fenicjanie, bliżsi dzisiejszym Turkom. W świetle obecnej wiedzy uzasadnione jest stwierdzenie, że wpływy helleńskie są bezsprzecznie widoczne w cypryjskiej kulturze materialnej dopiero od około połowy VI wie$\mathrm{ku}$, a oczywiste wpływy fenickie są wcześniejsze ${ }^{15}$.

Również we wczesnym średniowieczu wpływy semickie na społeczeństwo Cypru były znaczne. W VII wieku arabscy muzułmanie podbili część Cypru, czego wynikiem było wprowadzenie na wyspie, za milczącym przyzwoleniem Konstantynopola, rządów kondominium arabsko-bizantyjskiego i zasady neutralności. W 723 r. wyspę odwiedził pielgrzymujący do Ziemi Świętej angielski mnich, przyszły biskup i święty, Willibald i w swojej relacji z podróży zawarł opis sytuacji na Cyprze. Pisał o wyspie, ,inter graecos et sarracenos" ([która jest położona] między Grekami i Saracenami) i o Cypryjczykach, którzy ,nie posiadali broni, ponieważ był wielki pokój i zgoda pomiędzy Saracenami i Grekami" "16. Niektórzy historycy twierdzą, iż ocena ta odzwierciedla symbiozę dwóch społeczności żyjących obok siebie, w oddzielnych sektorach, grupach sektorów lub enklawach $^{17}$. Kronikarz arabski z X w. Ibn Haukal wspomina o terytorialnym podziale wyspy między mocarstwa i z satysfakcją mówi o dobrych stosunkach między chrześcijanami i muzułmanami ${ }^{18}$. Cypr został ostatecznie odbity z rąk muzułmanów dopiero w 964 r., za panowania cesarza Nicefora Fokasa (963-969).

${ }^{13}$ Termin eteocypryjski (Eteokyprier, prawdziwie cypryjski) został stworzony przez filologa Johannesa Friedricha w 1932 r. na określenie języka najwcześniejszych mieszkańców Cypru; z czasem został zaadaptowany jako przymiotnik określający pierwotnych mieszkańców wyspy. J. Friedrich, Kleinasiatische Sprachdenkmäler, Berlin 1932, s. 49-52. Por. M. Given, Inventing the Eteocypriots: Imperialist Archaeology and the Manipulation of Ethnic Identity, „Journal of Mediterranean Archaeology”, 11, 1998, s. 3-29.

${ }^{14}$ M. Iacovou, The Late Bronze Age Origins of Cypriot Hellenism and the Establishment of the Iron Age Kingdoms, [w:] From Ishtar to Aphrodite: 3200 Years of Cypriot Hellenism, red. S. Hadjisavvas, New York 2003, s. 79-85. Najprawdopodobniej fragment Iliady (XI, 20-23), mówiący, że kiedy Kinyras dowiedział się o planach wyprawy Achajów na Troję, podarował Agamemnonowi przepiękny pancerz, by 'łaskę króla pozyskać', jest późniejszą wstawką - i wczesnym przykładem propagandy - która miała na celu wskazanie, że Cypr był wtedy grecki raczej niż fenicki. Z. J. Kapera, Kinyras i Achajowie, „Zeszyty Naukowe UJ”, 232 (1970), s. 7-15; O. Panagi, Cyprus and Cypriots in the Homeric Poems, [w:] The History of the Greek Language In Cyprus, Nicosia 1988, s. 31-37.

${ }^{15}$ A. T. Reyes, Archaic Cyprus. A Study of the Textual and Archaeological Evidence, Oxford 1994, s. 127. Nie bez znaczenia dla jasnego obrazu historii fenickich wpływów może być fakt, że kiedy w latach 30 . XX wieku Cypryjczycy zaczęli się aktywnie interesować archeologią, entuzjazm ekipy pod kierunkiem Porphyriosa Dikaiosa był niezwykle selektywny i, jak zauważył gubernator Storrs, za jego urzędowania żadna z odkrywek z okresu fenickiego 'nie ostała się determinacji greckiej większości, że Cypr ma posiadać dowody jedynie helleńskiego pochodzenia'. R. Storrs, Orientations, London 1939, s. 488.

${ }^{16}$ Willibald, Hodoeporicon, [w:] Latin Texts from the First Century B.C. to the Seventeenth Century A.D., ed. L. Roberts, Albany 2000, s. 160; D. M. Metcalf, Byzantine Cyprus, 491-1191, Nicosia 2009, s. 404-405.

${ }^{17}$ C. P. Kyrris, The Nature of the Arab-Byzantine Relations in Cyprus from the middle of the 7 to the middle of the 10 century A.D., „Graeco-Arabica”, 3, 1984, s. 149-175, s. 158-159, 169-170; D. M. Metcalf, Byzantine Cyprus, s. 316, 429, 455.

${ }^{18}$ Chypre dans les sources arabes médiévales, ed. M. Tahar Mansouri, Nicosia 2001, s. 34; C. P. Kyrris, The Nature of the Arab-Byzantine Relations in Cyprus, s. 171-172. 
Wielu historyków (i to niekoniecznie arabskich czy tureckich) sugeruje, że powtarzające się semickie penetracje Cypru zmieniły całkowicie jego charakter etniczny. Dowody na ten punkt widzenia są sprzeczne i dodatkowo skomplikowane przez fakt, że ludy semickie od początku mieszały się ze sobą. Badania krwi pobranej od niewielkiej, ale statystycznie znaczącej, grupy w okresie brytyjskim wskazują, że współcześni Cypryjczycy są bliżej spokrewnieni z ludnością wybrzeża Syrii niż Grecji, ale bardziej wnikliwe badania kraniologiczne materiału dowodowego, zarówno z przeszłości jak i z współczesnych czasów, prowadzą do przeciwnych wniosków. Nie wdając się w rozważania dotyczące zasadności badań kraniologicznych, wyważony pogląd wydaje się wskazywać, że podczas gdy większość współczesnych Cypryjczyków to Europejczycy - w szerszym, rasowym sensie znaczenia tego słowa, to znaczny procent, szczególnie w miastach, posiada cechy azjatyckie, które mogą być jedynie rezultatem imigracji semickiej ${ }^{19}$.

Za panowania Lusignanów i Wenecjan (1191-1571) na Cyprze mieszkała jedynie niewielka grupa muzułmanów, składająca się z niewolników schwytanych w trakcie wypraw na wybrzeża Syrii i Egiptu ${ }^{20}$. Sytuacja zmieniła się znacznie po zajęciu Cypru przez Imperium Otomańskie w 1571 r. Celem sułtana było, aby Cypr odzyskał swój dawny dobrobyt, ale na przeszkodzie stała ciągle zmniejszająca się liczba mieszkańców wyspy. Przed podbojem Cypru przez Imperium Osmańskie wyspę zamieszkiwało ok. 197 tys. osób. Według spisu ludności z 1572 r., w wyniku wojny i emigracji liczba ta zmniejszyła się o ok. 50 tys. ${ }^{21}$ By zaradzić tej sytuacji, w dekadzie 1571-1581 sułtan wydał co najmniej sześć dekretów wzywających do emigracji na Cypr jedną dziesiątą ludności z kilku prowincji Anatolii. Ostatecznie rdzeń muzułmańskich mieszkańców stanowiło ok. 3-4 tys. spahisów i janczarów z armii Lala Mustafy, którym sułtan nadał ziemię oraz domy i którzy stanowili załogę fortec w Nikozji, Famaguście i Pafos, oraz ok. 8-12 tys. przesiedleńców z Azji Mniejszej. Chociaż imigranci muzułmańscy cieszyli się pewną przewagą nad chrześcijanami, zarówno jedni jak i drudzy byli uznawani za raja, w odróżnieniu od klas wojskowych, niedziedzicznych lenników ${ }^{22}$.

Za sprawą przesiedleń z Azji Mniejszej muzułmanie na zawsze stali się częścią ludności Cypru. Ta polityka przesiedleń, podobna zresztą do trwającej w tym samym okresie „plantacji” Anglików i Szkotów w Irlandii, miała w przyszłości doprowadzić do powstania

${ }^{19}$ Por. D. M. Metcalf, Byzantine Cyprus, 491-1191, s. 590-593: Blood groups, DNA, and Historical Demography; P. A. Clearkin, Blood Transfusion Service in Cyprus with Notes on the ABO Groups of Cypriots, „British Medical Journal” 5102, 1958, s. 939-942.

${ }^{20}$ B. Arbel, Slave Trade and Slave Labour in Frankish and Venetian Cyprus (1191-1571), ,Studies in Medieval and Renaissance History", 1993, n.s. vol. 14, s. 151-190.

${ }^{21}$ Większość mieszkała w 800-850 wsiach, w (pięciu) cypryjskich miastach mieszkało jedynie ok. 25 tys. osób. Zob. R. Jennings, The Population, Taxation, and Wealth in the Cities and Villages of Cyprus, According to the Detailed Population Survey (Defter-i Mufassal) of 1572, „Journal of Turkish Studies, Raiyyet Rusumu Essays Presented to Halil Inalcik", 10, 1986, s. 175-189.

${ }^{22} \mathrm{~W}$ archiwach otomańskich zachowała się bogata korespondencja z lat 1570-1590, dotycząca planów i praktycznych problemów związanych z przesiedleniami na Cypr. Zob. O. L. Barkan, Les déportations comme method de peuplement et de colonisation dans l'empire Ottoman, Revue de la Faculté des Sciences Economiques de l'Universite d'Istanbul, 1949-1950, 11, s. 67-131; R. C. Jennings, Forced Population Transfers and the Banishment of Undesirables, [w:] idem, Christians and Muslims..., s. 212-239; C. Orhonlu, The Ottoman Turks

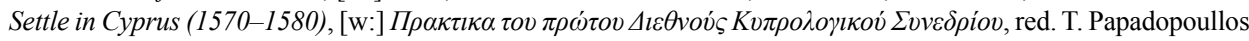
et al., t. 3A, s. 257-261. 
tzw. „problemu cypryjskiego”. Zachowane źródła różnią się jednak znacznie, jeśli chodzi o zmiany w populacji w okresie panowania imperium otomańskiego i podawane na ogół liczby są z konieczności bardzo szacunkowe ${ }^{23}$. Do liczby muzułmanów przesiedlonych z Anatolii należy dodać wcale liczną grupę tzw. linobambakoi, głównie łacińskich mieszkańców Cypru, którzy zdecydowali się przyjąć islam²4.

W 1862 r. H.P. White, brytyjski wicekonsul, tak opisywał mieszkańców wyspy:

Cypryjczycy są łagodni, pobłażliwi, towarzyscy i gościnni, lubią przyjemności. Jest w nich jednakże wrodzone lenistwo, zakorzenione nieróbstwo. Marnują wiele czasu w kawiarniach. Jeżdżą często na jarmarki urządzane raz po raz w różnych częściach wyspy. Prowadzą oszczędny i umiarkowany tryb życia - codzienną dietę chłopstwa stanowi chleb gruboziarnisty, ser, oliwki i warzywa. Jednakże, ponieważ wino leje się tu strumieniami, a w dodatku jest tanie, pijaństwo nie stanowi tu niecodziennego widoku. Rozboje, włamania i zabójstwa są czymś niemal niespotykanym, podobnie jak agitacja polityczna czy też sprzeciw wobec ustanowionej władzy.

Chrześcijanie są mniej fałszywi, choć zwykło się tak sądzić o Grekach; aczkolwiek w Lewancie znani są z przebiegłości i zamiłowania do prowadzenia interesów. Jest to opinia nie do końca nieuzasadniona. W tutejszych muzułmanach brak fanatyzmu i bigoterii, która charakteryzuje muzułmanów arabskich. Żyją w pokoju z chrześcijańskimi sąsiadami w mieście, jak i na wsi, choć ci mieszkający w Nikozji, gdzie stanowią większość populacji, lubią okazywać wyższośćc 5 .

Olbrzymia większość Cypryjczyków, zarówno chrześcijan jak i muzułmanów, mieszkała na wsi. Chłopi, mimo że nieprzywiązani już formalnie do ziemi, byli z nią ,złączeni” z czystej konieczności, ponieważ nie mieli dokąd pójść. Inną możliwością było albo przymieranie głodem, albo życie z rzadko dostępnej jałmużny. W konsekwencji duże rodziny były na porządku dziennym, a przetrwanie stało się etosem epoki. Chłopi nadal żyli w warunkach skrajnej nędzy i upokorzenia. Taka była brutalna rzeczywistość cypryjska. Wieśniak, ściśnięty przez „feudalne” więzy i średniowieczną biedę, miał tylko jedną drogę ucieczki - religię. Najpierw stał się przesądny, później bogobojny, więc ciągle się modlił o zbawienie swojej duszy, a uczestnictwo w kościelnych obrzędach i uroczystościach, takich jak śluby, chrzciny i święta, stanowiło jego jedyną rozrywkę. Życie muzułmanów na wsiach niewiele się różniło od życia chrześcijan.

Znacznie wzbogaciły się również kulturowe i folklorystyczne relacje pomiędzy dwiema społecznościami. Dotknięci biedą, odizolowani i niepiśmienni Cypryjczycy rozwinęli swoją własną kulturę ludową: muzykę, taniec, pieśni, opowieści i legendy, w których wyrażali siebie i swój duchowy świat. Poeci ludowi w prologach swoich napisanych po grecku wierszy, które recytowali na jarmarkach, wzywali do słuchania i chrześcijan, i muzułmanów, ponieważ wszystkie grupy brały udział w takich społecznościowych zabawach. Niektórzy muzułmanie pisali poezje po turecku według greckich zasad. O udanym współistnieniu i wzajemnych wpływach obydwu społeczności świadczyć może fakt, że muzułmanie na

${ }^{23}$ Zob. M. Misztal, Zmiany w populacji Cypru w okresie turkokracji (1570-1878) [w druku].

${ }^{24}$ Zob. M. Misztal, Linobambakoi, kryptochrześcijanie na Cyprze, [w:] Odmienność w kulturze, red. A. Rzepkowska, Toruń 2017, s. 113-128.

${ }^{25}$ Cyt. za: H. Luke, Cyprus under the Turks, 1571-1878, Oxford 1921, s. 209-210. 
Cyprze mówili po grecku, a w niektórych wioskach ich dzieci przedstawiały w szkołach greckie sztuki. Ponadto bliski związek pomiędzy dwoma językami przyczynił się do wzbogacenia cypryjskiej greki o dużą liczbę tureckich słów i wyrażeń ${ }^{26}$.

Wiele aspektów folkloru zarówno greckich jak i tureckich Cypryjczyków ma wspól-

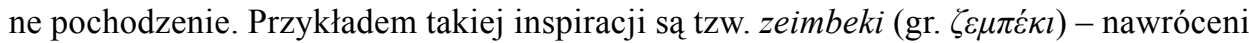
na islam sławni żeglarze i korsarze lub piraci z bizantyjskiego dystryktu Kibyrraiot, którzy współpracowali z Bizantyjczykami, Frankami, a w końcu również z Turkami. Ich sława, szczególnie jako piratów, rozpalała wyobraźnię na terenach greckich, tureckich

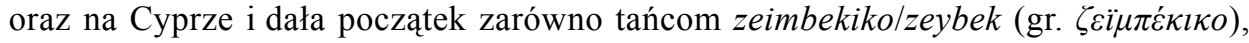
jak i tradycyjnym dzisiaj workowatym spodniom, zwanym vraka. Dzięki tradycjom związanym z zeimbeki istnieje wiele podobieństw między greckimi i tureckimi tańcami i muzyką 27 .

Greckie opowiadania, cypryjskie wiersze, a w szczególności akritika - ballady graniczne z Digenesem Akritasem w roli głównej, legendy o mitycznych postaciach i bohaterach, o starych budynkach i skarbcach, o duchach i chochlikach „kallikantzaroi” (gr. $k \alpha \lambda \lambda \imath \kappa \alpha ́ v \tau \zeta \alpha \rho o v)$ znane są zarówno wśród greckich, jak i tureckich Cypryjczyków. Badania wykazały, że niektóre ballady akritika istnieją w pełniejszych wersjach wśród tureckich Cypryjczyków z Karpasii czy Pafos niż wśród Greków, a charakterystyczną cechą cypryjskich wersji jest ostateczne zwycięstwo Digenesa nad Charonem (Śmiercią) ${ }^{28}$.

Ponadto zwyczaje i tradycje obydwu grup, z wyłączeniem czysto religijnych, są bardzo podobne, np. jeśli chodzi o przewidywanie płci dziecka, zaklęcia i panacea, wotywne ofiary, przygotowania do ślubu czy zwyczaje pogrzebowe. Tak jak jego grecki sąsiad, turecki Cypryjczyk wkładał owoc granatu między ziarno i zwracał się ku wschodowi przed jego posianiem. Podobnie nad grobami tureckich i greckich Cypryjczyków rozbijano gliniane naczynie. Można założyć, że są to dowody na długi okres pokojowego współistnienia i harmonijnego kontaktu pomiędzy dwiema społecznościami na Cyprze ${ }^{29}$.

Chociaż obraz mieszkających na wsiach Cypryjczyków jest przygnębiający, to odnieść by go można również do wielu innych krajów, gdzie również, podobnie jak na Cyprze, społeczeństwo nie było jednorodne. Towarzyska i ekonomiczna przepaść pomiędzy ludźmi bogatymi a wieśniakami, czy robotnikami, była ogromna. Inne grupy społeczne, np. lekarze, prawnicy, wykwalifikowani rzemieślnicy oraz nieliczni kupcy, radziły sobie znacznie lepiej niż chłopi pod tureckimi rządami. Niektórzy mieli możliwość kształcenia się i podróżowania za granicę, inni odegrali ważną rolę w pomaganiu biednym lub ,importowali” nowe myśli z innych krajów.

Niektórzy współcześni badacze twierdzą, że w ogóle nie było upolitycznienia konfliktów etnicznych na Cyprze przed przybyciem Brytyjczyków. Adamantia Pollis jest zdania, że

${ }^{26}$ F. Beckingham, The Turks of Cyprus, s. 168-172; M. Kappler, Toward a Common Turkish and Greek Literary History in Ottoman Cyprus, [w:] Ottoman Cyprus, s. 285-295. Na temat języka zob. R. Bryant, Signatures and 'Simple Ones': Constituting a Public in Cyprus circa 1900, [w:] Britain in Cyprus. Colonialism and Post-Colonialism, 1878-2006, ed. H. Faustmann and N. Peristanis, Monachium 2006, s. 82-83.

${ }^{27}$ B. Azgin, Y. Papadakis, Folklore, [w:] Zypern. Südosteuropa-Handbuch, red. K.-D. Grothusen et al., Göttingen 1998, s. 703-720.

${ }^{28} 27$ Centuries of Cypriot Poetry. An Anthology, red. Th. Kouyialis, Nicosia 1983, s. 25.

${ }^{29}$ C. P. Kyrris, Symbiotic Elements in the History of the Two Communities in Cyprus, s. 127-166; J. Asmussen, Patterns of Cypriot Identity or Why Cypriotism doesn't Exist, [w:] Culture in Common - Living Cultures in the Cypriot Communities, red. D. Pilavas, Berlin 2003, s. 9-12. 
konflikty, które istniały, miały miejsce między elitami, między otomańską administracją i hierarchami cypryjskiego Kościoła prawosławnego, i były walką o przywileje, władzę i kontrolę. Nie ma przykładu politycznych walk między Grekami a Turkami, czy muzułmanami a chrześcijanami.... Istniało zróżnicowane, ale zintegrowane społeczeństwo na poziomie wsi... Nie występowały konflikty.... Polityka i akcje wolnej Grecji i greckiego Kościoła ortodoksyjnego były niewystarczające i nieodpowiednie, by rozpalić na Cyprze grecki nacjonalizm... Społeczne realia codziennego życia Cypryjczyków, przynajmniej do pierwszych dekad XX w., były praktycznie niezmienne; nie zaistniały żadne niezależne wewnętrzne uwarunkowania, które przyspieszyłyby transformację tożsamości..... ${ }^{30}$

Taki „,idylliczny”, „rajski” wręcz obraz jest z pewnością nie do końca prawdziwy ${ }^{31}$. Prawdą jest, że warunki życia wieśniaków, tak muzułmanów jak i chrześcijan, były bardzo podobne. Prawdą jest też, że w wielu przypadkach obie grupy wspólnie brały udział w rebeliach, jak np. w latach 1665, 1764, 1830 i 1833. Nawet jeżeli rebelie organizowane były przez chrześcijan, popierali je niejednokrotnie również muzułmanie, doprowadzeni do ostateczności wyzyskiem i okrucieństwem urzędników i oficerów. Z ich punktu widzenia rebelie były nie tyle wymierzone w jakąkolwiek grupę wyznaniową czy narodowościową, ile skierowane przeciwko źle działającym administracji i systemowi podatkowemu, zarządzanemu tak przez muzułmańskich urzędników jak i - po 1754 r. - prawosławnych biskupów ${ }^{32}$, rosnącym kosztom utrzymania (spowodowanym głównie „rewolucją cen”) oraz powtarzającym się przypadkom branki najbardziej obiecujących młodych chłopców (prawo dewszirme), szkolonych głównie do pracy w administracji ${ }^{33}$.

Najpoważniejsza z rebelii przeciwko przedstawicielowi sułtana, w której udział brali zarówno chrześcijanie jak i muzułmanie, wybuchła w 1764 r., kiedy poborcą podatkowym (muhassilem) na wyspie został aga Çil Osman. Dążąc do jak najszybszego odzyskania zapłaconych za dzierżawę podatków kwot, nałożył na wszystkich chrześcijan podatek w wysokości 44,5 piastra $^{34}$, a na wszystkich muzułmanów - połowę tej kwoty. W reakcji na protesty chrześcijan i Turków groził nałożeniem dodatkowych podatków również na klasztory. Ostatecznie delegacja biskupów zdołała przekonać Portę o nielegalności działań muhassila i ta wysłała swojego przedstawiciela (çokedar) do zbadania sprawy i ukarania winnych na miejscu. Na prośbę muhassila formalne spotkanie z çodekarem $\mathrm{w}$ - obecności wszystkich ważnych urzędników i biskupów - odbyło się w jego pałacu. W czasie spotkania w komnacie ta część podłogi, na której stali duchowni chrześcijańscy, zapadła się, a oni

${ }^{30}$ A. Pollis, The Role of Foreign Powers in Structuring Ethnicity and Ethnic Conflict in Cyprus, [w:] Cyprus and its People, ed. V. Calotychos, Westview Press, 1998, s. 89, 91; Idem, International Factors and the Failure of Political Integration in Cyprus, [w:] Small States and Segmented Societies: National Political Integration in a Global Environment, ed. S. G. Neuman, New York 1976, s. 58.

${ }^{31}$ Th. Diez, Last exit to paradise? The European Union, the Cyprus and the problematic , catalytic effect”, [w:] The European Union and the Cyprus Conflict. Modern Conflict, Postmodern Union, ed. Th. Diez, Manchester 2002, s. 151-152.

${ }^{32}$ M. Misztal, Polityczna rola Kościoła prawosławnego, s. 21-23.

${ }^{33}$ C. P. Kyrris, Symbiotic Elements in the History of the Two Communities in Cyprus, [w:] International Symposium on Political Geography. Proceedings (Nicosia 1976), s. 129-131, 137-141, 154-156, 159-162; C. P. Kyrris, History of Cyprus, Nicosia 1985, s. 265-267; George Hill, History of Cyprus, 4 vols, Cambridge 1952, 4, s. 52-65.

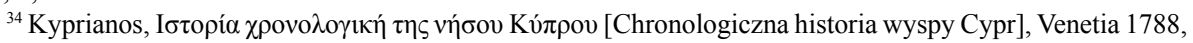
s. 355 , daje 47 piastrów. 
poranieni spadli do piwnicy. Po zbadaniu okazało się, że dźwigary zostały specjalnie podpiłowane. Próbowano też otruć çodekara, lecz udało się na czas podać mu antidotum. Greccy oraz tureccy przywódcy, oburzeni takim obrotem sprawy, zażądali ukarania $m u$ hassila, ale ten pozostawał głuchy na wezwania do stawienia się przed oblicze muzułmańskiego sędziego (molla). Wówczas Cypryjczycy, licznie zebrani w Nikozji z okazji dorocznego jarmarku, zareagowali gniewnie i zebrali się pod pałacem. Gdy oddziały Çil Osmana ostrzelały tłum, gawiedź wdarła się do środka, zabiła muhassila i osiemnastu jego urzędników, a następnie splądrowała i spaliła doszczętnie rezydencję. Tureckie władze, na czele z sędzią, zdołały przekonać sułtana, iż winę za zaistniałą sytuację ponosi wyłącznie Çil Osman i że wydarzenia nie miały nic wspólnego z rewoltą przeciwko władzy i autorytetowi sułtana. Mimo iż Cypryjczyków winnych zamieszek i śmierci Osmana nie spotkała żadna dotkliwa kara, musieli ponieść koszty odnowienia i wyposażenia rezydencji oraz finansowej rekompensaty (główczyzny) dla rodzin zamordowanych tureckich urzędników, co oszacowano łącznie na pół miliona piastrów ${ }^{35}$.

To, że nie było upolitycznienia przynależności etnicznej, nie oznacza, że podziały takie nie istniały w lokalnych społeczeństwach i że społeczeństwo było „całkowicie zintegrowane”. Nawet w mieszanych wsiach, gdzie ludność mówiła po grecku, społeczności chrześcijan i muzułmanów żyły obok siebie, ale jednak oddzielnie ${ }^{36}$. Muzułmanie na ogół utrzymywali przyjazne stosunki z prawosławnymi sąsiadami, chociaż powstrzymywali się od zakładania mieszanych rodzin; w przypadku chrześcijan mieszane małżeństwa były teoretycznie zakazane ${ }^{37}$. Wspólne używanie miejsc kultu, wspólne obchodzenie świąt i uroczystości, mieszane rady sołeckie, to wszystko wskazuje na częściową przynajmniej integrację obu społeczności ${ }^{38}$.

Nie do końca można się zgodzić z poglądem, że w przypadku ortodoksyjnego Kościoła ekumenicznego, z patriarchą w Konstantynopolu, tożsamość religijna reprezentowała „,proto-nacjonalizm”. Patriarchat uważał za swego głównego wroga nie muzułmanów czy Imperium, ale rzymski katolicyzm. Hierarchia Kościoła sprzeciwiała się greckiej rewolucji w 1821 r. ${ }^{39}$, ale lokalni popi pomimo faktu, że zostali ekskomunikowani przez patriarchę, zdecydowali się zachować swoje wpływy wśród wiernych i poparli rewolucję. Ta różnica

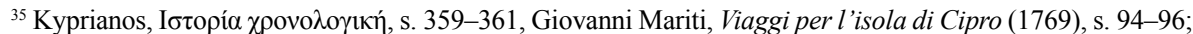

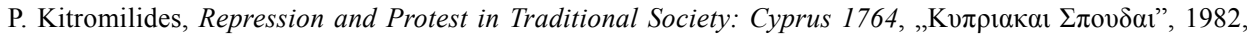
s. $91-101$.

${ }^{36}$ Zob. dyskusję w: A. F. Reiterer, Cyprus. Case Study about a Failure of Ethno-national Understanding, s. $31-35$.

${ }^{37}$ Ortodoksyjne prawo kanoniczne zakazywało małżeństw chrześcijan z muzułmanami, ale przepisy te nie powstrzymały wiernych od zawierania mieszanych małżeństw. Zob. V. D. Volkan, Cyprus - War and Adaptation,

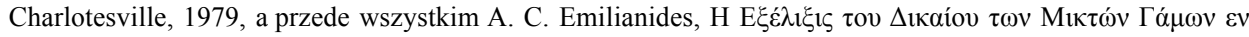

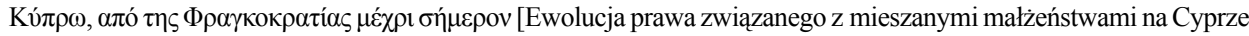

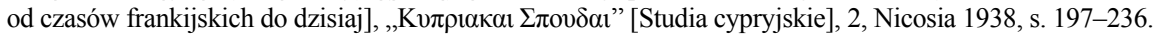

${ }^{38}$ M. Attalides, The Turkish Cypriots: Their Relations to the Greek Cypriots in Perspective, [w:] Cyprus Reviewed, ed. M. Attalides, Nicosia 1977, s. 74-76; P. M. Kitromilides, From Coexistence to Confrontation: The Dynamics of Ethnic Conflict in Cyprus, [w:] Cyprus Reviewed, s. 36-41; por. T. Bahcheli, Greek-Turkish Relations since 1955, Boulder, Westview Press 1990, s. 23, który twierdzi, że co prawda za panowania Otomanów nie było konfliktów między społecznościami, ale zawsze istniały dwie odrębne etniczne grupy z odrębnymi kulturami.

${ }^{39}$ T. Papadopoullos, Studies and Documents Relating to the History of the Greek Church and People under Turkish Domination, 2nd ed., Gower Publishing, 1990, s. 147-149.
} 
zdań doprowadziła do rozłamu, który trwał do $1850 \mathrm{r}{ }^{40}$ Podobnie rzecz się miała na Cyprze, gdzie hierarchia, zadowolona z przyznanych jej przez sułtana przywilejów, sprzeciwiała się jakimkolwiek ruchom, które mogłyby zagrozić status quo ${ }^{41}$.

Brytyjczycy przejęli Cypr w roku 1878. Celem polityki zagranicznej rządu Benjamina Disraelego było zachowanie za wszelką cenę integralności imperium osmańskiego, bo jego rozpad doprowadzić mógł do wojny między mocarstwami europejskimi, a to z kolei zagroziłoby wpływom brytyjskim na Bliskim Wschodzie, bezpieczeństwu Kanału Sueskiego oraz komunikacji z koloniami w Indiach i na Dalekim Wschodzie. Dlatego Disraeli zażądał od sułtana bazy (place d'armes), z której wojska brytyjskie mogłyby interweniować $\mathrm{w}$ razie zagrożenia status quo w regionie. W dniu 4 czerwca $1878 \mathrm{r}$. podpisano tajną konwencję brytyjsko-turecką o „obronnym przymierzu”, której głównym celem było powstrzymanie dalszej ekspansji Rosji na tureckie terytoria w Azji. Chociaż de iure do 1923 r. Cypr miał pozostać integralną częścią imperium osmańskiego, zatknięcie flagi brytyjskiej symbolizowało de facto przejęcie wyspy na następne 82 lata $^{42}$.

Dnia 22 lipca 1878 r. przybył na Cypr Sir Garnet Wolseley, mianowany przez królową Wiktorię królewskim komisarzem sprawującym najwyższą władzę na wyspie. Następnego dnia Wolseley odczytał proklamację skierowaną do ludności Cypru, w której zapewniał, że wszystkim mieszkańcom zostaną zagwarantowane „wolność, sprawiedliwość i bezpieczeństwo" i nikt na wyspie nie będzie uprzywilejowany ze względu na rasę czy religię. Nie tylko greccy, ale i tureccy Cypryjczycy, szczególnie ubożsi, powitali Brytyjczyków z radością i nadzieją na polepszenie warunków życia, wierząc, że nadszedł kres prześladowań, korupcji i nieudolności administracji ${ }^{43}$. „The Times” donosił też, że w Nikozji arcybiskup Sofronios (1865-1900) zapewnił, iż Cypryjczycy są pokojowo nastawieni i łatwo się nimi rządzi oraz że będą wierni i oddani nowej „ojcowskiej władzy”. Wyraził też nadzieję, że ten moment obwieszcza nowe życie i nową erę dobrobytu dla wyspy; że „my wszyscy, chrześcijanie i muzułmanie, nauczymy się, że prawo jest władcą wszystkiego..., że wszyscy mamy te same przywileje i obowiązki”. Sofronios chciał równości dla prawosławnych i muzułmanów, ale ani słowem nie wspomniał ani Grecji, ani enosis ${ }^{44}$.

Kilka lat po przybyciu Brytyjczyków, Herbert Kitchener, zwiedzając Cypr, zauważył, że brytyjski rząd jest popularny wśród Cypryjczyków:

we wsi Kethroea w sylwestra, kiedy zegary obwieściły początek nowego roku, obudziły nas głośne okrzyki i wiwaty na cześć Wiktorii i Anglików. Nie było z nimi żadnych Anglików, a wiwaty były całkowicie spontaniczne.... Turcy również są zadowoleni z nowych rządów. Nie prześladują ich zaptiehs (policja), nie obawiają się zaciagnięcia do wojska i raczej lubią Anglików ${ }^{45}$.

${ }^{40}$ Ch. A. Frazee, The Orthodox Church and Independent Greece, 1821-1852, Cambridge 1969.

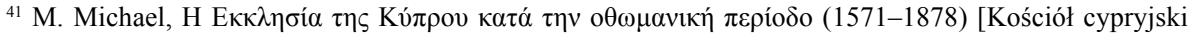
w okresie osmańskim (1571-1878)], Nicosia 2005, s. 230-235.

${ }^{42}$ M. Misztal, Historia Cypru, s. 377-379.

${ }^{43}$ „The Times”, 7 VIII 1878, s. 10a-b. Proklamacja Wolseleya z 22 VII 1878 w języku polskim, [w:] A. Adamczyk, Cypr. Dzieje polityczne, Warszawa 2000, s. 397.

${ }^{44}$ Mowa arcybiskupa Sofroniosa, [w:] A. Varnava, British Imperialism in Cyprus, 1878-1915, The Inconsequential Possession, Manchester 2009, Appendix VIII, s. 292-293. Zob. M. Misztal, Polityczna rola Kościoła prawosławnego, s. 28-30, na temat wykorzystywania przez enotystów sfabrykowanej mowy Sofroniosa po jego śmierci.

${ }^{45}$ H. Kitchner, Notes from Cyprus, „Blackwood's Magazine”, August 1879. 
Jedyną obawą tureckich Cypryjczyków było niebezpieczeństwo ewentualnego przyłączenia Cypru do Grecji.

W czasie tworzenia konstytucji nowo powstałego królestwa Grecji, którego władca od 1863 r. nosił tytuł króla nie Grecji, ale Hellenów, pojawiła się wizjonerska idea utworzenia państwa obejmującego wszystkie tereny zamieszkane przez ludność mówiącą po grecku, a obecnie znajdujące się pod obcym panowaniem. Ta wizjonerska i nacjonalistyczna idea

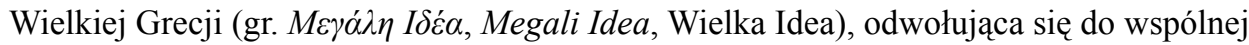
- helleńskiej - kulturowej przeszłości, miała swe korzenie w proroctwach i przepowiedniach, które pomagały Grekom przetrwać okres tureckiej niewoli. Z Megali Idea związane było dążenie do przyłączenia poszczególnych ziem do greckiej macierzy, zwane enosis (gr.

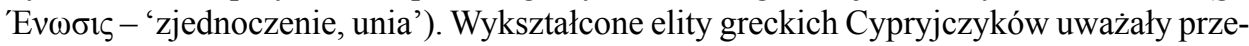
jęcie Cypru przez Wielką Brytanię za ważny krok w kierunku przekazania wyspy Grecji.

Po śmierci w 1900 r. arcybiskupa Sofroniosa, nastappiła zmiana w nastawieniu hierarchów Kościoła prawosławnego do (protestanckich) Brytyjczyków, w znacznym stopniu spowodowana ich krytycznym podejściem do istniejących pod panowaniem tureckim przywilejów Kościoła ortodoksyjnego i coraz częściej pojawiały się w oficjalnych adresach biskupów słowa „hellenizm” i ,enosis”. Brytyjczycy nie doceniali początkowo rozmiarów determinacji greckich Cypryjczyków w dążeniu do enosis i jeszcze w 1902 r. Chamberlain sugerował, że wolą oni podlegać bogatej Wielkiej Brytanii niż ubogiej Grecji ${ }^{46}$. Uważny skądinąd obserwator, konsul brytyjski R. Hamilton Lang, twierdził, że Cypryjczycy, a szczególnie chłopi, nie są wcale „zarażeni monomanią helleńskich aspiracji” ${ }^{47}$. Zlekceważył jednak wielki wpływ na zwykłych Cypryjczyków wiejskich prawosławnych popów, którzy, podobnie jak prawnicy, bankierzy i kupcy, wraz z przybyciem (protestanckich) Brytyjczyków stracili wiele przyznanych im przez sułtana przywilejów i stali się głównymi orędownikami przyłączenia Cypru do Grecji.

W 1901 r. Wysoki Komisarz na Cyprze, Haynes Smith, wyjaśniał Josephowi Chamberlainowi powody agitacji greckich Cypryjczyków za enosis:

Agitacja dotychczas ogranicza się do miast i do przedstawicieli wolnych zawodów, którzy na Cyprze są wyjątkowo liczni w porównaniu z populacją. Wielu z nich wyjeżdża do Aten, by uzyskać kwalifikacje adwokata czy lekarza... Wracają przepełnieni hellenistyczną propaganda. Ci ludzie, jako Cypryjczycy, nie mają obywatelstwa, bo zaprzeczają, że są poddanymi otomańskimi... Nie mają flagi i nie mają satysfakcji z naturalnego pragnienia przynależności do jakiegoś narodu... ${ }^{48}$

Jednocześnie, dodaje Haynes-Smith, elity te są zbyt młode, by z autopsji znać tragiczne skutki tureckiej administracji, i dlatego ciągle narzekają na rządy brytyjskie. Głównym powodem narzekań był brak możliwości rządzenia własnym krajem - uznając, że nadana im

${ }^{46}$ Parliamentary Debates, House of Commons, vol. 75, col. 1527 i vol. 108, cols 641 i 643: Przemówienie w Izbie Gmin z 4.08.1899 r. i z 26.05.1902 r. (Online: www.hansard-archive.parliament.uk/Parliamentary_Debates, data dostępu: 20.12.2017 r.). Ale zob. wcześniejszą opinię W. E. Gladstone’a, że im bogatszy będzie Cypr, tym bardziej Grekocypryjczycy będą dążyli do unii z „wolnymi Grekami reszty świata”. W. E. Gladstone, Political Speeches in Scotland, March and April 1880, Madison 1880, s. 289.

${ }^{47}$ H. Lang, Cyprus, London 1878, s. 202-203.

${ }^{48}$ National Archives, Kew, CO 883/6/, 357-360, Haynes-Smith to Joseph Chamberlain, 28 XI 1901. No. 221A, Confidential. 
przez Brytyjczyków konstytucja nie spełnia ich oczekiwań i daje zbyt duże prawa muzułmanom. O ile więc na początku rządów Brytyjczyków poparcie dla enosis nie było społecznym masowym ruchem ${ }^{49}$, to $\mathrm{z}$ upływem czasu sytuacja ta zmieniała się $\mathrm{w}$ dużej mierze $\mathrm{z}$ powodu istniejącego na Cyprze systemu edukacji, zaakceptowanego przez Brytyjczyków.

Wraz z podbojem tureckim kulturalne i edukacyjne standardy Cypryjczyków spadły do bardzo niskiego poziomu i jedynie nieliczni potrafili czytać i pisać. System edukacji rozwinął się dopiero w połowie XIX w., głównie dzięki staraniom ludzi Kościoła ${ }^{50}$. We wszystkich cypryjskich miastach i w części wsi założono szkoły podstawowe, finansowane przez diecezje, arcybiskupstwo, klasztory oraz zwykłych obywateli oraz nadzorowane przez komitety złożone z prałatów i osób świeckich. W założonej w 1812 r. Szkole Helleńskiej w Nikozji, która stanowiła wzór dla innych instytucji edukacyjnych, uczniowie studiowali prace greckich autorów oraz grecką historię, historię Kościoła, arytmetykę i geografię polityczną, uczyli się także języków tureckiego oraz francuskiego ${ }^{51}$.

O ile proces powstawania szkół wynikał z troski, jaką przejawiał Kościół wobec potrzeby edukacji i przez długi czas część nauczycieli stanowili księża, o tyle po uzyskaniu wolności przez Grecję edukacja na Cyprze z czasem rozwijała się dzięki wydatnej pomocy Greków. Nauczyciele szkolili się w greckich placówkach edukacyjnych lub byli po prostu Grekami, którzy przybyli pracować na wyspie. Cypryjska oświata nabrała charakteru narodowego. Program nauczania skupiony był na utożsamianiu się Cypryjczyków z grecką historią, kulturą oraz tradycjami i chociaż proces ten miał swój początek w miastach, stopniowo dotarł również do szkół wiejskich ${ }^{52}$.

Pierwsza szkoła turecka została założona na Cyprze już w 1578 r. Od 1824 r. dzieci, tak chłopcy jak i dziewczęta, które ukończyły 4 lata, 4 cztery miesiące i 4 dni do ukończenia 7 lat, a od 1869 r. w wieku od 6 do 11 lat, musiały obowiązkowo chodzić do bezpłatnej szkoły, zwykle stanowiącej część meczetu. Obok podstaw pisania i czytania szkoły muzułmańskie ukierunkowane były początkowo jedynie na nauczanie religii, głównie poprzez zapamiętywanie fragmentów Koranu, ale w wyniku reformy kształcenia z 1871 r. do programu nauczania dodano geografię i historię ${ }^{53}$. W chwili przejęcia Cypru przez Brytyjczyków, na Cyprze istniało 85 greckich i 65 tureckich szkół podstawowych na ponad 137 tys. chrześcijan i ponad 45 tys. muzułmanów ${ }^{54}$.

${ }^{49}$ A. Pollis, The Role of Foreign Powers in Structuring Ethnicity and Ethnic Conflict in Cyprus, s. 91; P. Loizos The Progress of Greek Nationalism in Cyprus 1878-1976, 1974, s. 116-118.

${ }^{50}$ Co prawda już w 1583 r. byli na Cyprze ,,publiczni nauczyciele”, ale pierwszą grecką szkołę założył arcybiskup Filoteos (1734-1759); jednak wkrótce popadła ona w ruinę. W 1808 r. mnich Joannikos przekazał swój dom, w którym dzięki szczodrości dragomana Hajigeorgiakisa Kornesiosa założono szkołę pod nazwą

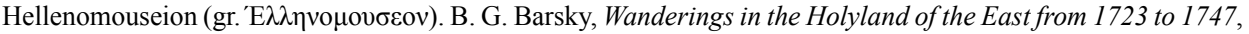
St. Petersburg 1886, s. 241; M. N. Michael, An Orthodox Institution of Ottoman Political Authority: The Church of Cyprus, [w:] Ottoman Cyprus, s. 209- 230; Th. Stavrides, Cyprus 1750-1830: Administration and Society, [w:] Ottoman Cyprus, s. 92-93.

${ }^{51}$ W. W. Weir, Education in Cyprus. Some Theories and Practices in Education in the Island of Cyprus since 1878, Nicosia 1952; G. Hill, History of Cyprus, vol. 4, s. 345-346, 354-355, 368, 372-373.

52 Por. Y. Papadakis, Narrative, Memory and History Education: A Comparison of Greek Cypriot and Turkish Cypriot Schoolbooks on the „History of Cyprus”, „History and Memory”, 20, nr 2 (2008), s. 128-148.

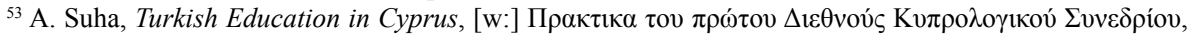
3A: 355-375; A. C. Gazioğlou, The Turks in Cyprus, s. 195-209.

${ }^{54}$ Command Paper, no. 4264: Report on the Census of Cyprus, 1881, ed. F. W. Barry, [w:] Accounts and Papers, 1884-1885, t. 53, s. 1-57. 
Do końca lat 20. XX w. brytyjskie władze liberalnie traktowały edukację, pozostawiając ją w rękach obu społeczności i wbrew swej zwykłej polityce kolonialnej, wspierającej język angielski, pozwalały na używanie w szkołach greckiego lub tureckiego. Szkoły, do których uczęszczały dzieci greckich Cypryjczyków, zwykle realizowały ten sam program nauczania, co szkoły w Grecji, zaś szkoły tureckich Cypryjczyków - taki jak w Turcji, a więc w sposób naturalny patriotyzm i lojalność uczniów skupiały się na Grecji lub Turcji. Obok kościołów szkoły - kontrolowane zresztą w większości nadal przez prawosławny kler - były główną amboną do propagowania idei enosis i w ten sposób zostały one zaszczepione wśród mieszkańców wsi ${ }^{55}$. Do przybycia Brytyjczyków głównym powodem podziału wśród Cypryjczyków była religia, teraz dodany został nacjonalizm.

Ze strony tureckiej, nacjonalizm nie rozwinął się jeszcze, ponieważ imperium było tworem wieloetnicznym, dla którego tego typu ruchy stanowiły śmiertelne zagrożenie ${ }^{56}$. Gwarantem jedności była religia, co odzwierciedlał program nauczania w szkołach Turkocypryjczyków. Inaczej było wśród Grekocypryjczyków. Tu pożywką dla nacjonalizmu była helleńska historia i język - katarewusa, czyli jego uczona, sztuczna postać, a nauczyciele z czasem stawali się propagandystami enosis ${ }^{57}$. Jeszcze bardziej niebezpieczne było jednak to, że podręczniki importowane z Grecji przedstawiały Turków jako odwiecznych wrogów wszystkiego co helleńskie. Tak więc wielowiekowe, jeżeli nie przyjazne, to przynajmniej tolerancyjne współistnienie i wzajemne zrozumienie między zwykłymi, prostymi mieszkańcami Cypru zostało podkopane, a ziarno nieufności zasiane. Turkocypryjczycy zaczęli zdawać sobie z tego sprawę i coraz częściej stawali się sprzymierzeńcami Brytyjczyków, widząc w nich obrońców przed grecką większością ${ }^{58}$.

Potwierdzeniem zainteresowania greckich Cypryjczyków przyłączeniem do Grecji był entuzjazm, wywołany w 1880 r. przygotowaniami do ewentualnej wojny z Turcją. Cypryjczycy wysłali stu pięćdziesięciu ochotników, gotowych służyć „swej ojczyźnie... wraz z modlitwą w intencji spełnienia się panhelleńskiej idei”"59. Rząd, zaniepokojony progreckimi nastrojami i angażowaniem się Cypryjczyków w konflikty między zaprzyjaźnionymi z Wielką Brytanią państwami oraz zasypywany protestami posłańców sułtana i oburzonych tureckich Cypryjczyków, 18 maja ogłosił dekret o neutralności Cypru.

${ }^{55}$ H. C. Luke, D. J. Jardine, The Handbook of Cyprus, London 1920, s. 136-146. Dopiero w 1923 r. władze kolonialne ograniczyły uprawnienia zarządzających szkołami podstawowymi komitetów, w 1929 r. nauczyciele stali się urzędnikami służby cywilnej, niemniej programy nauczania objęto kontrolą dopiero w 1933 r. Nadal jednak zarówno greckie, jak i tureckie szkoły średnie, utrzymywane z czesnego i dobrowolnych datków, pozostawały pod kontrolą Kościoła lub społeczności tureckich Cypryjczyków i z czasem w coraz większym stopniu rozpalały w uczniach emocje nacjonalistyczne. R. Storrs, Orientations, London 1937, s. 585-589; G. Georghallides, A Political and Administrative History of Cyprus, 1918-1926, 6: with a Survey of the Foundations of British Rule, Nicosia 1979, s. 47-52.

${ }^{56}$ Chociaż również w Imperium Osmańskim istniała grupa intelektualistów, którzy budowali podstawy tureckiego etnonacjonalizmu. Przykładem Ziya Gokalp (1876-1924), który rozczarowany pomysłami otomanizmu i islamizmu, wprowadził do „tureckiej” historii i etnografii wiele fantastycznych elementów, był piewcą Turanu, mitycznej ojczyzny i utożsamiał przodków Turków z Hunami. Por. A. F. Reiterer, Cyprus. Case Study about a Failure of Ethno-national Understanding, s. 30.

${ }^{57}$ The National Archives, Kew, Richmond, Records of the Colonial Office, Commonwealth and Commonwealth Offices; Colonial Office: CO 67 Cyprus, Original Correspondence (cyt. jako NA CO) 67/128: Dispatch of W.F. Haynes-Smith, 28.11.1901; NA CO 67/132: Dispatch of W.F. Haynes-Smith, 30.08.1902, par. 7, wraz z załączonym ,A Report on the Hellenic Propaganda in Elementary Schools”, 4.08.1902.

${ }^{58}$ Por. NA CO 67/132: opinię zawartą w raporcie W. F. Haynes-Smitha, 30.08.1902, par. 6.

${ }^{59}$ S. Pantelli, A New History of Cyprus, London 1984, s. 64. 
W 1897 r. w związku z tzw. wojną trzydziestodniową między Grecją i Turcją grecki konsul Filemon ${ }^{60}$ potajemnie zwerbował około tysiąca cypryjskich ochotników, którzy wyróżnili się w czasie bitwy pod Welestino. Udział Cypryjczyków w walkach przeciwko prawowitemu władcy wyspy, sułtanowi, wywołał protesty tureckich mieszkańców, którzy przypominali, że Brytyjczycy są jedynie jej administratorami ${ }^{61}$. Rok 1898 ponownie rozbudził wśród greckich Cypryjczyków nadzieje na enosis, gdy po licznych powstaniach ludności greckiej na Krecie europejskie mocarstwa zdecydowały się przekazać wyspę w administrację greckiemu księciu Jerzemu ${ }^{62}$. Kreta została ostatecznie włączona do Grecji w 1908 r., ale mieszkający na wyspie Turcy zapłacili za to krwawą cenę ${ }^{63}$, a los kreteńskich muzułmanów miał stać się często przywoływanym ostrzeżeniem, co może się zdarzyć na Cyprze, i przekonał cypryjskich muzułmanów, że należy przeciwstawiać się enosis z całą mocą.

Ważnym momentem w historii stosunków między obiema społecznościami na Cyprze była wizyta w październiku 1907 r. Winstona Churchilla, ówczesnego parlamentarnego podsekretarza stanu do spraw kolonii. Churchill spotkał się z reprezentantami obu społeczności, a w odpowiedzi na memoriał greckich Cypryjczyków stwierdził, że nie może rozmawiać o politycznym statusie wyspy, ale osobiście uważa za rzecz jak najbardziej naturalną, iż z powodu swego ,greckiego pochodzenia” dążą do połączenia z ,macierzą”. To dążenie jest bowiem przykładem „,patriotycznych uczuć, które są tak szlachetną cechą greckiego narodu”. Zaraz potem dodał jednak, że opinie ludności muzułmańskiej również muszą być przez rząd brane pod uwagę z całym poszanowaniem i że przyłączenie Cypru do Grecji łamałoby ustalenia konwencji z $1878 \mathrm{r}^{64}$

Mimo że w dalszym ciagu zarówno greccy, jak i tureccy Cypryjczycy przekazywali wysokiemu komisarzowi lub wysyłali do rządu w Londynie niezliczone memoriały, listy, petycje i sprzeciwy ${ }^{65}$, na wyspie nie dochodziło do poważniejszych zatargów między obie-

${ }^{60}$ Grecki rząd, w trosce o dobre stosunki z Wielką Brytanią, nie tylko oficjalnie nie popierał enosis, ale nawet gdy Filemon raz po raz prowokacyjnie organizował lokalne olimpiady, będące okazją do zamanifestowania progreckich sympatii i niechęci do Wielkiej Brytanii, w 1900 r. odwołał go z placówki na życzenie Londynu. NA CO 883/6, 223, Enclosure in Foreign Office to Colonial Office, 15 March 1900, NA CO 67/128, Raport W.H. Haynesa-Smitha, 28 XI 1901, wraz z załącznikami.

${ }^{61}$ Zob. proklamację Wysokiego Komisarza, Waltera J. Sendalla w „The Cypriot Gazette”, 23 IV 1897.

${ }^{62}$ Zob. NA CO 883/6, 103, Haynes-Smith to Chamberlain, 27 Dec 1898, który donosił, że ,grecka społeczność jest bardzo poruszona wydarzeniami na Krecie. Miały miejsce różne demonstracje na wyspie związane z tym wydarzeniem, pod przewodnictwem przedstawicieli greckiego Kościoła. Rozumiem, że nowa organizacja powstała w Atenach, aby doprowadzić do takiej samej sytuacji na Cyprze... Turecka społeczność protestuje przeciwko tym demonstracjom, które są źródłem rosnącej urazy”. Haynes-Smith miał tu na myśli organizację pod

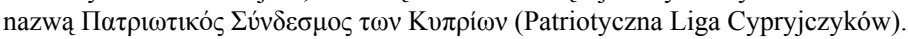

${ }^{63}$ Nie do końca jest pewne, ilu Turków zostało zamordowanych przez Greków, ale - inaczej niż w przypadku „okrutnej masakry” dokonanej przez Turków po powstaniu w Bułgarii w 1875 r. - europejska opinia publiczna nie zwróciła większej uwagi na ten wczesny przykład dokonanej przez chrześcijan czystki etnicznej. Zob. The Situation in Crete, The Times, 5 VIII 1902. Por. W. E. Gladstone, Bulgarian Horrors and the Question of the East, London 1876.

${ }^{64}$ NA CO 67/149: Mr. Churchill's Reply to the Greek Elected Members); opinia Churchilla jest często cytowana jako poparcie idei enosis, ale z pominięciem jego uwag o prawach muzułmańskiej mniejszości. Zob. M. Misztal, Churchill's Visit to Cyprus in 1907: Enosis and Constitutional Issues, „Annales Universitatis Paedagogicae Cracoviensis. Studia Anglica", z. 3, 2013, s. 158-178.

${ }^{65}$ Zob. np. NA CO 67/160, 99, King-Harman to Earl of Crewe, 9 September 1910; NA CO 67/161, 124, Tevfik Pasha to Grey, 8 September 1910; NA CO 69/27, 101, 102, 103: Minutes of the Legislative Council, 30 March 1911. 
ma społecznościami. Sytuacja zmieniła się w 1912 r. W wyniku wojny włosko-tureckiej (wojna trypolitańska) Włosi zajęli w porozumieniu z Francją Libię (oprócz Tobruku) oraz archipelag Dodekanez. Utrata przez Imperium wysp na Morzu Egejskim była dobrą wiadomością dla greckich Cypryjczyków, którzy już widzieli oczyma wyobraźni, że Cypr będzie następny, tym bardziej że w maju 1912 r. Grecja dołączyła do zawartego w marcu antytureckiego sojuszu państw bałkańskich (Bułgarii i Serbii), zmierzającego do odebrania Turcji Macedonii. Informacje te wprawiły greckich Cypryjczyków w ekstazę, zaś tureckich Cypryjczyków, pamiętających dobrze wydarzenia z Krety, napełniły obawami o ich przyszłość. Brytyjski Wysoki Komisarz na Cyprze, Goold-Adams, podsumował sytuację w następujący sposób:

Nie ma potrzeby, abym zwracał waszą uwagę na powody, które w normalnych warunkach powodują wzrost, tu i gdzie indziej, wrogości między muzułmanami i greckimi chrześcijanami. Te uczucia zostały wzmocnione na Cyprze w okresie ostatnich sześciu miesięcy z dwóch powodów, tj. wzmożonej agitacji wśród greckich chrześcijan dotyczącej przyłączenia wyspy do Grecji, podniecających przemówień chrześcijańskich liderów, artykułów w greckiej prasie, i szyderstw rzucanych w oczy muzułmanom co do szybkiego końca imperium osmańskiego z rąk Italii, szczególnie od czasu przejęcia tureckich wysp na Morzu Egejskim. Z drugiej strony, muzułmanie są bezsprzecznie przybici rezultatami obecnej wojny z Włochami, i wielu fanatycznych członków stało się szczególnie wyczulonych na jakiekolwiek antyotomańskie uwagi czynione przez greckich chrześcijan ${ }^{66}$.

Już w kwietniu 1911 r. muzułmańscy przedstawiciele w Radzie Legislacyjnej głośno skarżyli się na ataki na muzułmanów w mieszanych wsiach ${ }^{67}$ i prowokacyjne artykuły

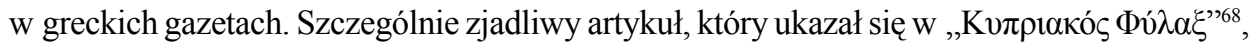
i zaczynał się od słów: „Obecność Turków wśród cywilizowanych nacji, a nawet rządy tureckie nad nimi, są obelgą i wstydem dla samej cywilizacji”, doprowadził do masowych protestów tureckich Cypryjczyków ${ }^{69}$. W październiku 1911 r. urzędnik brytyjski na Cyprze, C. W. Orr, opublikował proklamację w specjalnym wydaniu „Cyprus Gazette”, nakazującą wszystkim mieszkańcom Cypru zachowanie spokoju i całkowitej neutralności w związku z toczącą się wojną między Włochami i Turcją ${ }^{70}$. Wkrótce jednak ekscytacja po obu stronach sięgnęła zenitu. W piątek 24 maja 1912 r. grupa uczniów z chrześcijańskiej szkoły w Nikozji wspólnie z nauczycielami została - według ich wersji wydarzeń - obrzucona kamieniami przez grupę muzułmanów, kiedy hałasując i grając na trąbkach, paradowali przez muzułmańską wieś Mandres (Hamitkőy), podczas powrotu z pikniku do domu. We-

${ }^{66}$ NA CO 883/7, Goold-Adams to Secretary of State, 30 May 1912, s. 132. Podobną opinię wyraża raport do Ministerstwa ds. Kolonii, The King's Advocate in Cyprus, Mr Bucknill, to the Colonial Office, NA CO 67/168, 18 June 1812 , s. 298.

${ }^{67}$ NA CO 69/27, 390-394, 406-407: Minutes of the Legislative Council, 9 May 1911; NA CO 69/28, 88, Minutes of the Legilative Council, 22 April 1912, daje przykład wsi Angastina, gdzie muzułmańscy mieszkańcy czekają jedynie na sprzedanie swoich posesji i wyniesienie się gdzie indziej.

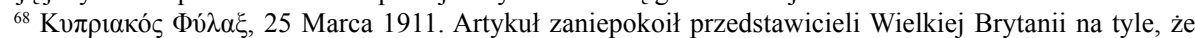
wysłali jego tłumaczenie do Londynu. NA CO 67/162, 317-320, Enclosure in Major Clauson to Harcourt, 30 June 1911.

${ }^{69} 21$ września 2011 r. 3000 osób zebrało się w Nikozji i innych miastach, by zaprotestować i przyjąć potępiającą takie praktyki rezolucję. NA CO 67/164, 175-176; Enclosure in Goold-Adams to Harcourt, 27 November 1911; ,Vatan”, 25 September 1911.

${ }^{70}$ „Cyprus Gazette”, 7 October 1911. 
dług muzułmanów, chłopcy wraz z nauczycielami weszli nieproszeni do trzech muzułmańskich domów, a gdy właściciele chcieli ich zaprowadzić na policję, zaczęli uciekać. W trakcie szarpaniny jeden z profesorów został ranny w głowę ${ }^{71}$.

Dużo bardziej dramatyczny przebieg miały wydarzenia w Limassol trzy dni później, w nocy 27 maja 1912 r., gdzie doszło do krwawego starcia między greckimi i tureckimi Cypryjczykami ${ }^{72}$. Kilku chrześcijan obrzuciło kamieniami dwa wozy z muzułmanami udającymi się z wioski Malia do meczetu. W odpowiedzi jeden z nich wyciągnął nóż i zaatakował dwóch napastników. Dzwony kościoła zwołały na pomoc chrześcijan i rozpoczęła się szarpanina, ale kiedy policja otworzyła ogień, tłum się rozproszył ${ }^{73}$. O ile nie było wątpliwości, że konflikt wywołali greccy chrześcijanie ${ }^{74}$, to istniały rozbieżne zdania, co do tego, czy ich działanie było z góry zaplanowane ${ }^{75}$. W czasie zamieszek 3 osoby zostały zabite, a 100 ranionych, od strzałów policji zginęły 2 osoby, a 9 odniosło rany. Rannych zostało także 14 policjantów oraz 1 oficer $^{76}$. W wyniku dochodzenia 18 osób skazano na karę więzienia od 9 miesięcy do 15 lat $^{77}$. W celu ,złagodzenia wrogości” między mieszkańcami Cypru gubernator wprowadził jednak częściową amnestię dla skazanych ${ }^{78}$.

Był to pierwszy poważny zbrojny konflikt między greckimi i tureckimi Cypryjczyka$\mathrm{mi}^{79}$. Wydawało się, że kilka miesięcy potem problem Cypru zostanie rozwiązany zgodnie z życzeniem greckich Cypryjczyków, bo pod koniec 1912 r. David Lloyd George w imieniu rządu brytyjskiego zaproponował liberalnemu greckiemu premierowi Elefteriosowi

${ }^{71}$ Cyprus National Archives, Secretariat Archives, SA1 1303/1912: Disturbances at Mandres near Nicosia on 24 May 1912: A. Moslem Account, B. The Greek Christian Account. W wyniku dochodzenia oskarżono o czynną napaść na chrześcijan 7 muzułmanów; brak źródeł o wyniku postępowania sądowego.

${ }^{72}$ Materiały źródłowe dotyczące tego incydentu, w olbrzymiej większości niewykorzystane jeszcze przez historyków, znajdują się w brytyjskich National Archives w Kew, NA CO 67/166, NA CO 67/167, NA CO 883/7/10, NA FCO 141/2352 oraz w Cyprus National Archives, Nicosia, Secretariat Archives, SA1 876/1912 Disturbances; SA1 1171/1912 Prosecutions in connection with Limassol riots, SA1 965/1912, SA1 1064/1912, SA1 1030/1912.

${ }^{73}$ NA CO 883/7, Goold-Adams to Secretary of State, 2 August 1912, 143.

${ }^{74}$ NA CO 67/167, 261 Minute (bez daty): ,Jeden fakt jest bezsporny, to jest, że nie można obarczać Turków winą za rozpoczęcie konfliktu. Należy zauważyć, że większość oskarżonych (i skazanych) stanowią Grecy”. The King's Advocate in Cyprus, Mr Bucknill, zakończył jednak swój raport, że ,żadna ze stron nie była bez winy”. Łatwo zauważyć, że grekocypryjscy historycy przekonują, że za wydarzenia odpowiedzialność ponoszą jedynie muzułmanie i Brytyjczycy, np. C. P. Kyrris, Peaceful Co-Existence in Cyprus under British Rule, 1878-1959 and After Independence: An Outline. Nicosia 1977, s. 39-40.

${ }^{75}$ Tak twierdzili tureccy Cypryjczycy. Zob. NA CO 883/7, 164, Enclosure no 3 in Goold-Adams to Secretary of State, 24 October 1912. Ale chociaż Colonial Office uważało za „,bardzo prawdopodobne”, że te zarzuty były prawdziwe, i nawet jeden z przedstawicieli greckich Cypryjczyków w Radzie Legislacyjnej powiedział, że „,nie obwinia Turków", nie zdecydowano się opublikować tej opinii w oficjalnym raporcie. NA CO 883/7, 161-162, Minute of 5 February 1913.

${ }^{76}$ NA CO 883/7, 143, Goold-Adams to Secretary of State, 2 August 1912.

${ }^{77}$ Szczegółową listę skazanych daje NA CO 67/170, 88-89, Enclosure in Clauson to Harcourt, 26 June 1913.

${ }^{78}$ NA CO 67/170, 86, Clauson to Harcourt, 26 June 1913.

${ }^{79} \mathrm{Nie}$ licząc zwykłych kłótni między przedstawicielami obu społeczności, które wybuchały między sąsiadami szczególnie po nadmiernym spożyciu alkoholu (również przez muzułmanów). Przykładem zaatakowanie muzułmanów przez pijanego greckiego Cypryjczyka, którym był Costa Pandelli, co doprowadziło do obrzucenia kamieniami posterunku policji i aresztowania 8 kompanów Pandellego. Cyprus Archives, Nicosia, Secretariat Archives, SA1 1249/1991, leaf 1-2: Disturbance at Asha, 9 July 1911. Tureckojęzyczna gazeta „Vatan” nazwała to wydarzenie ,przerażającym przykładem nienawiści i niechęci pielęgnowanej przez Greków w stosunku do muzułmanów”. „Vatan”, No 47, 17 July 1911, SA1 1249/1911 leaf 10. 
Wenizelosowi przekazanie Grecji Cypru w zamian za bazę w Argostoli na wyspie Kefalinia, ale rząd grecki, podzielony w swych preferencjach politycznych, odmówił ${ }^{80}$. Podobna sytuacja miała miejsce podczas I wojny światowej. Po klęsce wojsk entente cordiale pod Gallipoli, 12 września 1915 r. Bułgaria wypowiedziała wojnę Serbii. Ponieważ oznaczało to niebezpieczeństwo dla wojsk sprzymierzonych stacjonujących w Salonikach, Wielka Brytania ponownie zaoferowała Grecji Cypr w zamian za przystapienie do wojny i pomoc Serbii. W proniemieckim rządzie greckim przeważyła jednak opinia, że Grecja powinna pozostać neutralna ${ }^{81}$.

Decyzje rządu Grecji poważnie rozczarowały greckich Cypryjczyków, a konflikt między oboma społecznościami narastał, by wybuchnąć w latach 1956-1960 i doprowadzić do śmierci setek często postronnych osób. Wydarzenia zaś z roku 1974 r., zakończone zajęciem północnej części Cypru przez wojska tureckie dały początek trwającego do dzisiaj impasu, nazywanego ,problemem cypryjskim”.

\section{Bibliografia}

Źródła archiwalne:

The National Archives, Kew, Records of the Colonial Office, Commonwealth and Commonwealth Offices

NA CO $67 / 128$

NA CO $67 / 132$

NA CO $67 / 149$

NA CO $67 / 160$

NA CO $67 / 161$

NA CO $67 / 162$

NA CO $67 / 164$

NA CO $67 / 166$

NA CO $67 / 167$

NA CO $67 / 168$

NA CO $67 / 170$

NA CO $69 / 27$

NA CO $69 / 28$

NA CO $883 / 6$

NA CO $883 / 7$

NA FCO 141/2352

Cyprus National Archives, Secretariat Archives, Nicosia

SA1 876/1912

SA1 965/1912

SA1 $1030 / 1912$

SA1 $1064 / 1912$

SA1 1171/1912

${ }^{80}$ Zob. M. Misztal, The 1912 British Offer of Cyprus to Greece and the Reaction of the Greek and Muslim Cypriots. A British Perspective, „Almanach Historyczny”, 19, 2017, s. 93-107.

${ }^{81}$ Zob. M. Misztal, The Offer of Cyprus to Greece in 1915: A British Diplomatic Failure, „Studia Historyczne", 57, z. 4, 2014, s. 473-491. 
SA1 1249/1911

SA1 1303/1912

Asmussen J., Patterns of Cypriot Identity or Why Cypriotism doesn't Exist, [w:] Culture in Common - Living Cultures in the Cypriot Communities, red. D. Pilavas, Berlin 2003, s. 9-12.

Attalides M., The Turkish Cypriots: Their Relations to the Greek Cypriots in Perspective, [w:] Cyprus Reviewed, ed. M. Attalides, Nicosia 1977, s. 71-100.

Aymes M., A Provincial History of the Ottoman Empire. Cyprus and the Eastern Mediterranean in the Nineteenth Century, translated Adrian Morfee, London 2014.

Bahcheli T., Greek-Turkish Relations since 1955, Boulder, Westview Press 1990.

Barkan O. L., Les déportations comme method de peuplement et de colonisation dans l'empire

Ottoman, Revue de la Faculté des Sciences Economiques de l'Universite d'Istanbul, 1949-1950, 11, s. $67-131$.

Beckingham F., The Turks of Cyprus, The Journal of the Royal Anthropological Institute of Great Britain and Ireland, No 2, July-December 1957, s. 165-174.

Bryant R., Signatures and 'Simple Ones': Constituting a Public in Cyprus circa 1900, [w:] Britain in Cyprus. Colonialism and Post-Colonialism, 1878-2006, ed. H. Faustmann and N. Peristanis, Monachium 2006, s. 79-98.

Chypre dans les sources arabes médiévales, ed. M. Tahar Mansouri, Nicosia 2001.

Diez Th., Last exit to paradise? The European Union, the Cyprus and the problematic ,catalytic effect', [w:] The European Union and the Cyprus Conflict. Modern Conflict, Postmodern Union, ed. Th. Diez, Manchester 2002, s. 139-162.

Divided Cyprus: Modernity, History, and an Island in Conflict, ed. Yiannis Papadakis, Nicos Peristianis, Gisela Welz Bloomington: University of Indiana, 2006.

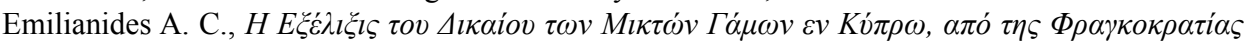
$\mu \varepsilon^{\prime} \chi \rho \imath$ б́́ $\mu \varepsilon \rho o v$ [Ewolucja prawa związanego z mieszanymi małżeństwami na Cyprze od czasów frankijskich do dzisiaj], Kvлpı $\alpha \kappa \alpha 1 \Sigma \pi 0 v \delta \alpha 1$ [Studia cypryjskie], 2, Nicosia 1938, s. $197-236$.

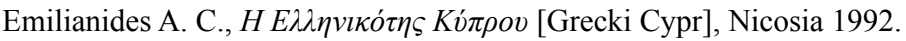

Etman A., History of Cyprus: The Island of Beauty and Pain from Antiquity to the Present Day, thum. $\mathrm{z}$ arabskiego Ahlam Fathy Hassan, Cairo 2002.

Gazioğlu A. C., The Turks in Cyprus, Nicosia-London 1990.

Georghallides G., A Political and Administrative History of Cyprus, 1918-1926, 6: with a Survey of the Foundations of British Rule, Nicosia 1979.

Given M., Inventing the Eteocypriots: Imperialist Archaeology and the Manipulation of Ethnic Identity, ,Journal of Mediterranean Archaeology”, 11, 1998, s. 3-29.

Griffiths P., Memories of Violence in Cyprus: Conflicting Perspectives and Dynamics of Reconciliation, niepublikowana praca doktorska, University of Exeter, 2011.

Hill G., History of Cyprus, 4 vols, Cambridge 1952.

Iacovou M., The Late Bronze Age Origins of Cypriot Hellenism and the Establishment of the Iron Age Kingdoms, [w:] From Ishtar to Aphrodite: 3200 Years of Cypriot Hellenism, red. S. Hadjisavvas, New York 2003, s. 79-85.

Kitromilides P., From Coexistence to Confrontation: The Dynamics of Ethnic Conflict in Cyprus, [w:] Cyprus Reviewed, ed. M. Attalides, Nicosia 1977, s. 35-70.

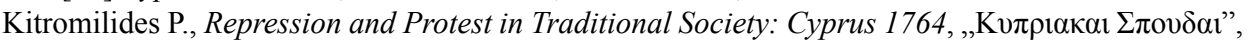
1982, s. 91-101.

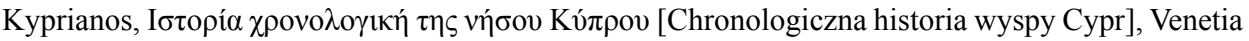
1788. 


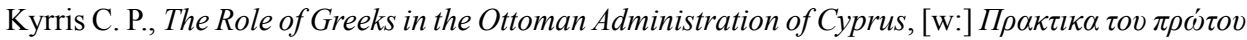

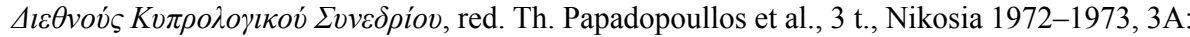
$155-179$.

Kyrris C. P., Symbiotic Elements in the History of the Two Communities in Cyprus, [w:] International Symposium on Political Geography. Proceedings, Nicosia 1976, s. 127-166.

Kyrris C. P., Peaceful Co-existence in Cyprus under British Rule (1878-1959) and after Independence: An Outline, Nicosia 1977.

Kyrris C. P., The Nature of the Arab-Byzantine Relations in Cyprus from the middle of the 7 to the middle of the 10 century A.D., „Graeco-Arabica”, 3, 1984, s. 149-175.

Kyrris C. P., History of Cyprus, Nicosia 1985.

Lang H., Cyprus, London 1878.

Loizos P., The Progress of Greek Nationalism in Cyprus 1878-1976, London 1974.

Luke H., Cyprus under the Turks, 1571-1878, Oxford 1921.

Luke H. C., Jardine D. J., The Handbook of Cyprus, London 1920.

Metcalf D. M., Byzantine Cyprus, 491-1191, Nicosia 2009.

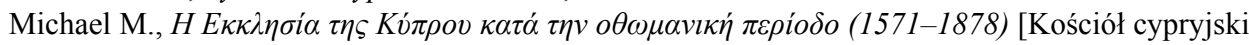
w okresie osmańskim (1571-1878)], Nicosia 2005.

Misztal M., Historia Cypru, Kraków 2013.

Misztal M., Churchill's Visit to Cyprus in 1907: Enosis and Constitutional Issues, Annales Universitatis Paedagogicae Cracoviensis. Studia Anglica, z. 3, 2013, s. 158-178.

Misztal M., Problem cypryjski a 'wojna kulturowa', [w:] Polska, Europa Środkowa, Europa Zjednoczona: księga jubileuszowa dedykowana profesorowi Józefowi Łaptosowi, red. Andrzej Kozera et al., Kraków 2014, s. 255-268.

Misztal M., The Offer of Cyprus to Greece in 1915: A British Diplomatic Failure, „Studia Historyczne", 57, z. 4, 2014, s. 473-491.

Misztal M., Polityczna rola Kościoła prawosławnego na Cyprze w okresie turkokracji i na poczatku panowania brytyjskiego, Studia Środkowoeuropejskie i Bałkanistyczne, t. XXIV, 2016, s. 15-34.

Misztal M., Linobambakoi, kryptochrześcijanie na Cyprze, [w:] Odmienność w kulturze, red. Aleksandra Rzepkowska, Toruń 2017, s. 113-128.

Misztal M., The 1912 British Offer of Cyprus to Greece and the Reaction of the Greek and Muslim Cypriots. A British Perspective, Almanach Historyczny, 19, 2017, s. 93-107.

Öksüzoğlu O., Persecution of Islam in Cyprus. A Document of Real Greek Intentions towards Muslim Turlish Cypriots, Nicosia 1982.

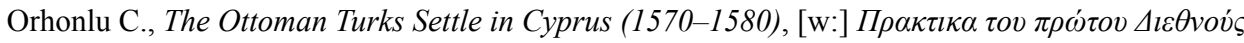

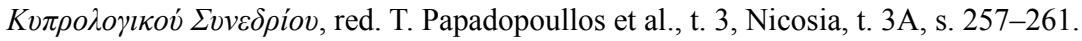

Ottoman Cyprus. A Collection of Studies on History and Culture, ed. M. N. Michael, M. Kappler, E. Gavriel, Wiesbaden 2009.

Papadakis Y., Narrative, Memory and History Education: A Comparison of Greek Cypriot and Turkish Cypriot Schoolbooks on the „History of Cyprus”, „History and Memory”, 20, nr 2 (2008), s. $128-148$.

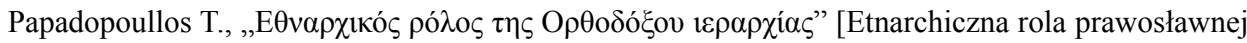

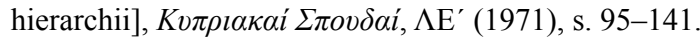

Pollis A., The Role of Foreign Powers in Structuring Ethnicity and Ethnic Conflict in Cyprus, [w:] Cyprus and its People, ed. Vangelis Calotychos, Westview Press, 1998, s. 87-104.

Pollis A., International Factors and the Failure of Political Integration in Cyprus, [w:] Small States and Segmented Societies: National Political Integration in a Global Environment, ed. Stephanie G. Neuman, New York 1976, s. 44-78. 
Reiterer A. F., Cyprus. Case Study about a Failure of Ethno-national Understanding, Peter Lang, Frankfurt am Main 2003.

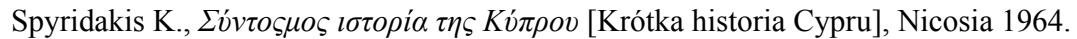

Storrs R., Orientations, London 1937.

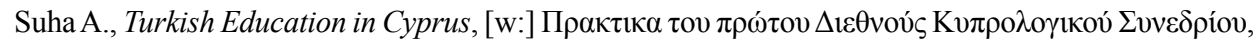
3A: 355-375.

Varnava A., British Imperialism in Cyprus, 1878-1915. The Inconsequential Possession, Manchester 2009.

Volkan V. D., Cyprus - War and Adaptation, Charlottesville 1979.

Weir W. W., Education in Cyprus. Some Theories and Practices in Education in the Island of Cyprus since 1878, Nicosia 1952.

Mariusz Misztal, dr hab., profesor Uniwersytetu Pedagogicznego w Krakowie, historyk i filolog; jego główne zainteresowania badawcze dotyczą okresu wiktoriańskiego oraz historii Cypru, przede wszystkim okresu panowania brytyjskiego. Autor pierwszej w języku polskim kompleksowej historii Cypru. 